\title{
PENGEMBANGAN EKONOMI PRODUKTIF BAGI KELOMPOK TANI PEMBUDIDAYA IKAN DI KABUPATEN LEBONG MELALUI PENGEMBANGAN AGRIBISNIS IKAN SEPAT SIAM
}

\section{PRODUCTIVE ECONOMIC DEVELOPMENT FOR AQUACULTURE FARMERS GROUP THROUGH AGRIBUSINESS DEVELOPMENT OF SEPAT SIAM FISH IN LEBONG}

\author{
Oleh: \\ Irnad, Reswita, Dewi Purnama \\ (Fakultas Pertanian Universitas Bengkulu)
}

\begin{abstract}
Sumber Rezeki Farmers Group and Maju Bersama Farmers Group are the farmers group existing at Tabeak Kauk village within 150 km from Bengkulu City. Sumber Rezeki Farmers Group and Maju Bersama Farmers Group were formed in 1999 with 20 members of each. One of the activities of farmer groups is fish farming. The most dominant fish cultivated by the farmers is the Goldfish, but a byproduct of farming Goldfish is Siamese Snakeskin fish. Siamese Snakeskin fish during this time include wild fish due to grow and multiply without cultivated by farmers. Snakeskin fish when cultivated intensively will provide enormous benefits for the economic development of members of farmer groups and villagers at Tabeak Kauk village, besides the easiness in the maintenance, the value of Siamese Snakeskin fish can be increased into dried fish. However, there are some problems faced by farmers' groups. The first problem is the limited availability of water to irrigate the pond. Contributing factor is the limited availability of water to irrigate their pool as a result having a lot of dead fish, there is even a farmer who can not do the fish farming until the rainy season comes because irrigation water was insufficient to irrigate their pool. The second problem is the high price of fish feed, the result are unoptimal fish growth and low production. The third problem is the problem of handling / processing after harvest. During this time, the fish is sold in fresh and is not accompanied processing activities, consequently the price of fish sold cheap, because if the fish was not immediately sold, those fish will rot. The fourth problem is the organization / group entrepreneurial for post-harvest processing of fish has not been there. Based on the problems faced, the purpose of this IbM activities are: 1) provide knowledge transfer partners in developing the cultivation of Siamese Snakeskin fish conjoined with a tarp, ranging from the spread of seeds, production management / maintenance, and harvesting, 2) provide knowledge transfer to farmers about how to manufacture Siamese Snakeskin fish feed, 3) increase the added value of fish production and farmers' income through diversification of products of Siamese Snakeskin fish into dried fresh and dried salted fish, 4) form an entrepreneurial group that has creativity and independent spirit. Methodology of Science and technology for the Community approach (IbM) will be delivered with extension and cultivation practices, feed manufacturing training, manufacture of dried fish training, and the formation of entrepreneurial groups. Results of IbM activity were members of farmers have the
\end{abstract}


knowledge and skills of fish farming intensively in pool tarp, feed manufacturing, increase the added value of the cultivation of fish, trigger creative spirit of farmers in creating refined products based food fish healthy and practical, as well as publications local and national scientific.

Keywords: Siamese Snakeskin fish Farming, Post-Harvest Processing, IbM

\section{PENDAHULUAN}

Kelompok tani Sumber Rezeki dan kelompok tani Maju Bersama adalah kelompok tani yang terdapat di desa Tabeak Kauk yang berjarak $\pm 150 \mathrm{~km}$ dengan Kota Bengkulu. Kelompok tani Sumber Rezeki dan kelompok tani Maju Bersama dibentuk tahun 1999 dengan jumlah anggota masing-masing 20 orang. Kegiatan anggota kelompok tani adalah melakukan usaha tani padi satu kali dalam satu tahun, usaha budidaya ikan mas, beternak itik dan ayam, dan bekerja sebagai buruh pertanian. Kegiatan budidaya ikan utama yang diusahakan kelompok tani adalah budidaya ikan mas dan ikan nila. Produk sampingan yang dihasilkan dari kegiatan budidaya ikan ini adalah ikan sepat siam, ikan kepala timah, dan ikan betok. Kegiatan budidaya dilakukan di kolam sawah dan dilaksanakan setelah panen padi selesai. Usaha budidaya ikan utama ini masih dilakukan secara sedehana dengan memanfaatkan air irigasi yang berasal dari pegunungan untuk mengairi kolam dan pembatas antara kolam dengan petani ikan lainnya adalah pematang sawah dengan ketinggian 0.5 meter.

Ikan sepat siam juga sangat berpotensi untuk dikembangkan di desa Tabeak Kauk ini. Ikan sepat siam selama ini termasuk ikan liar karena tumbuh dan berkembangbiak tanpa dibudidayakan oleh petani. Ikan sepat siam apabila dikembangkan secara lebih intensif akan dapat mencukupi kebutuhan semua kalangan masyarakat, dapat menambah pendapatan petani, sekaligus dapat mengembangkan potensi wilayah sebagai sentra produksi ikan yang mampu meningkatkan taraf perekonomian masyarakat tani desa Tabeak Kauk. Menurut Rukmana (2010) ikan sepat siam merupakan salah satu ikan yang layak dibudidayakan secara intensif berpola komersial (agrobisnis) di kolam dan perairan umum, apabila hasil melimpah ikan sepat siam dapat diolah dalam skala industri menjadi ikan asin. Ikan sepat siam ini sangat digemari oleh masyarakat karena kandungan gizinya yang tinggi dan rasanya yang lezat, baik dalam bentuk segar maupun sudah diolah menjadi ikan asin.

Pengembangan usaha budidaya ikan sepat siam ini sangat didukung oleh tersedianya lahan yang luas, pakan alami ikan yang melimpah seperti dedak, keong mas, bekicot, dan jenis kerang-kerangan dan tersedianya pasar untuk menampung dan memasarkan hasil produksi seperti rumah tangga, pedagang ikan, pasar tradisional, warung-warung dan rumah makan. Ikan sepat siam disamping kandungan gizi yang sangat tinggi untuk kebutuhan gizi masyarakat, ikan sepat siam ini memiliki prospek untuk dijadikan produk ciri khas dan produk unggulan Tabeak Kauk. Dengan dikembangkan usaha budidaya ikan sepat siam ini secara intensif dan diiringi dengan teknologi pengolahan hasil yang tepat dapat dijadikan lapangan usaha mampu memberdayakan dan menggerakkan perekonomian masyarakat. 
Namun demikian semua usaha budidaya ini dalam pengembanganya masih dihadapkan pada masalah kecukupan ketersediaan air untuk mengairi kolam karena air irigasi yang ada tidak mencukupi untuk mengairi kolam-kolam yang diusahakan oleh Kelompok tani dan masyarakat di desa Tabeak Kauk umumnya. Apabila air tersedia untuk mengairi kolam, usaha budidaya ini dapat dilakukan selam 3 kali setahun, tetapi karena air terbatas usaha budidaya hanya dapat dilakukan sekali dalam satu tahun. Mahalnya harga pakan juga menjadi dilema bagi anggota kelompok tani karena mereka tidak mampu untuk membelinya untuk memberi makan ikan-ikan yang mereka budidayakan. Pakan yang diberikan hanya seadanya berupa dedak yang pemberiannya ditebar di kolam dengan frekuensi pemberian 2 kali sehari. Meskipun memiliki sumber bahan baku pakan yang melimpah petani belum mampu memproduksi pakan buatan sendiri karena keterbatasan pengetahuan dan keterampilan mereka dalam menyusun formula pakan ikan yang tepat. Menurut Susanto (2006), pakan yang bergizi diperlukan membantu pertumbuhan yang optimal. Kekurangan pakan dalam waktu yang cukup lama menyebabkan ikan mudah terserang penyakit dan akhirnya mati. Selain itu, pada saat panen produksi melimpah ikan dijual dengan harga yang sangat murah karena belum ada upaya untuk mengolah ikan-ikan hasil panen tersebut menjadi produk olahan yang bernilai jual lebih tinggi seperti mengolah ikan-ikan tersebut menjadi ikan kering.

Berdasarkan uraian diatas, dalam kegiatan IbM ini akan diperkenalkan teknik budidaya dalam kolam terpal untuk mengatasi permasalah air, teknik pembuatan pakan ikan, dan pengolahan pasca panen untuk meningkatkan nilai tambah sehingga dapat membantu pengembangan ekonomi produktif bagi kelompok tani pembudidaya ikan dan masyarakat sekitarnya.

Mitra dalam kegiatan IbM ini adalah Kelompok tani Sumber Rezeki dan kelompok tani Maju Bersama adalah kelompok tani yang terdapat di desa Tabeak Kauk. Permasalahan yang dihadapi oleh mitra kelompok tani dalam mengembangkan usaha budidaya ikan dikelompokkan menjadi tiga. Permasalahan pertama adalah keterbatasan ketersediaan air untuk mengairi kolam. Berdasarkan informasi dari anggota kelompok tani dilapangan selama 3 tahun terakhir mereka mengalami kesulitan dalam melakukan budidaya ikan. Faktor penyebabnya adalah keterbatasan ketersediaan air untuk mengairi kolam mereka akibatnya banyak ikan yang mati, bahkan ada petani yang tidak bisa melakukan budidaya ikan sampai musim penghujan datang karena air irigasi yang ada tidak mencukupi untuk mengairi kolam mereka. Permasalahan kedua adalah terbatasnya pengetahuan dan keterampilan petani dalam menyusun formula dan membuat pakan ikan sendiri akibatnya pertumbuhan ikan tidak optimal dan produksi masih rendah. Permasalahan ketiga adalah keterbatasan pengethuan dan keterampilan petani dalam penanganan/pengolahan pasca panen. Selama ini ikan-ikan hanya dijual dalam bentuk segar dan tidak diiringi kegiatan pengolahan, saat panen ikan dijual dengan harga yang murah karena kalau tidak segera dijual 
ikan-ikan tersebut akan menjadi busuk. Permasalah keempat adalah organisasi/ kelompok kewirausahaan untuk pengolahan hasil pasca panen ikan selama ini belum ada. Berdasarkan permasalahan yang dihadapi mitra, maka kegiatan IbM ini memiliki tujuan:

1. Memberikan alih pengetahuan mitra dalam mengembangkan usaha budidaya ikan sepat siam dengan menggunakan kolam terpal, mulai dari pembuatan kolam, manajemen produksi/pemeliharaan, dan panen.

2. Memberikan alih pengetahuan kepada petani tentang cara menyusun formula dan pembuatan pakan ikan sepat siam.

3. Meningkatkan nilai tambah produksi ikan dan pendapatan petani melalui diversifikasi produk ikan sepat siam menjadi ikan sepat kering tawar dan ikan sepat kering asin.

4. Membentuk kelompok kewirausahaan yang memiliki jiwa kreatifitas dan mandiri.

Mengkaji permasalahan utama yang dihadapi oleh petani yaitu keterbatasan ketersediaan air selama kegiatan budidaya yang sering menyebabkan kolam petani mengalami kekeringan dan menyebabkan ikan-ikan mati karena sistem pengairan kolam selama ini mengandalkan air irigasi, maka untuk memecahkan permasalahan ini didemonstrasikan teknik budidaya ikan sepat siam dalam kolam terpal. Anggota kelompok tani akan diberi pelatihan mulai dari cara pembuatan kolam terpal, teknik pemeliharaan ikan sepat siam dalam kolam terpal. Adapun tujuan dan manfaat dari teknologi budidaya ikan dengan kolam terpal antara lain adalah dapat menghemat air karena terpal adalah bahan yang kedap air, menghemat biaya produksi, pertumbuhan ikan lebih cepat, waktu produksi lebih cepat, meningkatkan pemanfaatan lahan kering yang biasanya digarap sekali setahun dengan komoditas tertentu saja menjadi lahan produktif sepanjang tahun dengan komoditasnya beraneka ragam, meningkatkan pendapatan petani/pengelolanya dengan melakukan beberapa diversifikasi usaha (Kordi dan Ghufran, 2010). Kolam terpal sangat efektif dan efisiensi dan dapat disinergikan dengan kegiatan lainnya, dengan memanfaatkan pakan alami berupa sayur dan dedaunan yang ada disekitarnya, menghemat pupuk untuk pertanian karena air buangan limbah dan kegiatan budidaya ikan mengandung pupuk organik.

Untuk mengatasi keterbatasan pengetahuan dan keterampilan dalam menyusun formulasi yang tepat dan teknik pembuatan pakan dilakukan pelatihan tentang cara menyusun formula pakan yang tepat dan cara pembuatannya. Sebagaimana diketahui, pakan dalam budidaya ikan menyumbang sekitar $60-70 \%$ dari total biaya produksi (Sahwan dan Firdaus, 2004). Salah satu cara untuk meminimalkan biaya tinggi dengan membuat pakan ikan sendiri melalui teknik yang sederhana dengan memanfaatkan bahan baku lokal yang relative murah. Pakan yang berkualitas baik mengandung zat-zat makanan yang cukup yaitu: protein yang mengandung asam amino esensial, karbohidrat, lemak, vitamin dan mineral. Kekurangan vitamin dapat mengakibatkan kelainan pada bentuk tubuh dan fungsi organ pada ikan. Lebih lanjut hal ini mengakibatkan lambatnya pertumbuhan dan rendahnya sintasan sehingga sangat merugikan pembudidaya. Kekurangan vitamin ini juga menyebabkan ikan rentan terhadap serangan penyakit bakterial dan jamur yang dapat mengakibatkan kerugian yang lebih besar lagi. Kekurangan protein berarti kekurangan asam amino yang merupakan zat yang diperlukan untuk ketahanan tubuh, sehingga kekurangan 
protein menyebabkan ikan menjadi mudah terserang penyakit infeksi .Kekurangan asam lemak essensial menyebabkan perubahan warna dan erosi pada sirip serta masuknya lemak kedalam hati akibatnya menyebabkan pembengkakan pada hati dan kekurangan darah. Hal ini menebabkan lemahnya pertahanan tubuh ikan dan lambatnya pertumbuhan. Adapun beberapa bentuk pakan yang dikenal antara lain emulsi, tepung, remah dan pellet. Bahanbahan untuk pembuat pakan terdiri dari jagung, dedak, bungkil kedelai, tepung ikan, minyak kelapa, minyak ikan, vitamin mix, mineral mix, dan CMC (Afrianto dan Liviawaty, 2005).

Untuk penangan pasca panen akan dilakukan pelatihan bagi anggota kelompok tani tentang bagaimana membuat ikan kering sepat siam dalam bentuk ikan kering tawar dan ikan sepat siam asin. Setelah itu, anggota kelompok tani dan ibu-ibu PKK akan didampingi bagaimana mendesain kemasan yang menarik, pemberian merk, pendaftaran dan izin pendirian usaha. Agar usaha ini berkelanjutan akan dibentuk kelompok kewirausahaan yang tujuannya adalah untuk pemberdayaan ekonomi kelompok tani agar dapat meningkatkan pendapatan mereka, mengurangi pengangguran, dan menumbuhkan kemandirian ekonomi bagi anggota kelompok tani dan masyarakat desa Tabeak Kauk.

Luaran yang diharapkan adalah:

1. Produk/barang berupa ikan sepat siam segar yang memiliki gizi tinggi dan rasa yang enak.

2. Pakan ikan yang dapat disimpan dalam jangka waktu yang cukup lama.

3. Ikan sepat siam kering rasa tawar dan ikan sepat siam asin yang dikemas dalam kemasan yang menarik, memiliki merk, serta harganya terjangkau untuk semua kalangan masyarakat sehingga mampu menjadi bisnis yang mandiri, kompetitif, dan berdaya saing dimasa yang akan datang.

4. Terbentuknya kelompok usaha bersama

5. Publikasi jurnal ilmiah lokal dan nasional

Selain itu, dengan adanya kegiatan pengabdian pada masyarakat ini dapat memberikan manfaat bagi setiap lapisan masyarakat, seperti petani, masyarakat, dan pemerintah, yang antara lain:

\section{Manfaat Bagi Petani}

1. Memiliki pengetahuan dan keterampilan budidaya ikan secara intensif dalam kolam terpal.

2. Memperoleh penghasilan yang dapat dipergunakan untuk menghidupi diri sendiri dan keluarganya.

3. Memperoleh kesempatan untuk meningkatkan kompetensi keterampilannya.

4. Sarana untuk mengolah jiwa kewirausahaan yang akan menjadi bekal untuk berwirausaha, menambah wawasan dan pengalaman petani dalam berkarya serta menerapkan teknologi sederhana yang berhasil guna. 
5. Memicu jiwa kreatif petani dalam menciptakan sebuah produk pangan olahan baru yang bermanfaat bagi tubuh, sehat dan praktis.

\section{Manfaat Bagi Masyarakat}

1. Tumbuhnya aneka mata pencaharian baru yang diusahakan masyarakat.

2. Berkurangnya pengangguran dan kemiskinan.

3. Produk ini akan membantu konsumen dalam pemenuhan lauk bergizi tinggi

4. Berkurangnya kesenjangan sosial dan gangguan keamanan.

\section{Manfaat Bagi Pemerintah Daerah}

1. Peningkatan kualitas SDM.

2. Peningkatan pertumbuhan ekonomi dan PAD.

3. Pengurangan arus urbanisasi dan kerawanan sosial.

\section{METODE PENGABDIAN}

Metode pelaksanaan kegiatan yang diterapkan dalam upaya untuk mencapai tujuan program adalah metode pemberdayaan masyarakat yang dikenal dengan nama metode PALS (Participatory Action and Learning System) yang dikembangkan oleh Linda Mayouk pada tahun 2000 (Chambers, 2007). Metode PALS ini merupakan salah satu metode yang masuk dalam lingkup metode PLA (Participatory Learning Action) yang merupakan hasil perubahan dari metode RRA (Rapid Rural Appraisal). Beberapa prinsip dasar dari metode PALS ini adalah; 1) menempatkan masyarakat di desa sasaran sebagai objek dan sekaligus sebagai subjek kegiatan; 2) pelaksanaan program menggunakan berbagai pendekatan; 3) pelaksanaan program berfokus pada kebutuhan atau kepentingan masyarakat; 4) programprogram memiliki sifat pemecahan masalah, pemberdayaan masyarakat dan pengembangan wilayah; 5) pelaksanaan program bersifat sistemik; dan 6) pelaksanaan program bersifat mencerdaskan dan meransang aktivitas masyarakat.

Metode pendekatan Ipteks bagi Masyarakat ( $\mathrm{IbM}$ ) ini akan disampaikan dengan beberapa tahapan. Tahap-tahap kegiatan pengabdian pada masyarakat ini dimulai dengan persiapan, pelaksanaan, dan evaluasi.

Tahap Persiapan meliputi:

1. Koordinasi dengan Tim Pelaksana Kegiatan tentang rencana yang akan dilakukan untuk melaksanakan kegiatan.

2. Mengurus izin kegiatan dengan membawa surat tugas dari Lembaga Pengabdian pada Masyarakat UNIB ke kantor desa Tabeak Kauk Kabupaten Lebong.

3. Berkoordinasi dengan kelompok tani mengenai jadwal kegiatan.

4. Menyiapkan tempat dan materi penyuluhan.

5. Menyiapkan alat-alat dan bahan yang digunakan untuk pelatihan

6. Menggandakan handout yang akan dibagikan kepada peserta

Tahap Pelaksanaan meliputi:

1. Penyuluhan tentang budidaya ikan sepat siam dari hulu sampai hilir

2. Demplot Pembuatan Kolam Terpal 
3. Praktek pelatihan pembuatan pakan ikan

4. Praktek pembuatan ikan kering tawar dan asin (Anonym, 2014)

5. Pembentukan kelompok usaha bersama dan pendampingan analisis usaha yang berkelanjutan

\section{Evaluasi:}

Evalusi hasil pelaksanaan kegiatan dengan kriteria indikator pencapaian tujuan seperti minat dan kehadiran peserta dalam setiap kegiatan, tingkat adopsi peserta yang diukur dengan melihat perkembangan penerapan paket teknologi yang diberikan dan kesinambungan paket teknologi yang telah dicapai.

\section{Partisipasi Mitra IbM}

Dalam program IbM ini, anggota kelompok tani dilibatkan mulai dari proses perencanaan, proses pelaksanaan hingga proses monitoring dan evaluasi kegiatan. Dalam tahap perencanaan, tim pelaksana program IbM mengajak anggota kelompok tani untuk ikut merencanakan kegiatan yang akan dilaksanakan. Pada tahap ini tim pelaksana IbM menggali informasi dari masyarakat tentang hal-hal yang diperlukan dan diinginkan oleh masyarakat dan tentang potensi-potensi yang ada di desa yang dapat dipakai sebagai modal untuk memenuhi keperluan dan keinginan masyarakat. Informasi tentang hal-hal yang diperlukan dan potensi-potensi yang dimiliki oleh masyarakat ini kemudian dipakai dasar oleh tim pelaksana untuk merencanakan bentuk-bentuk kegiatan. Dalam tahap pelaksanaan, anggota kelompok tani secara bersama-sama diajak untuk melaksanakan kegiatan dengan difasilitasi oleh tim pelaksana program IbM. Dalam kegiatan yang berbentuk penyuluhan, anggota kelompok tani di posisikan sebagai peserta (sasaran) penyuluhan. Sementara penyuluhnya sendiri diperankan oleh sejumlah pakar yang diambil dari UNIB. Dalam kegiatan yang berbentuk pendidikan dan pelatihan, anggota keompok tani diposisikan sebagai peserta pelatihan, sedangkan tutor dan narasumbernya diperankan oleh tim pelaksana IbM. Dalam kegiatan yang berbentuk pembinaan dan pendampingan terhadap analisis usaha anggota kelompok tani diposisikan sebagai pihak yang dibina dan didampingi. Sementara itu pembina atau pendampingnya diperankan oleh tim pelakasana program IbM. Dalam kegiatan yang berbentuk pembangunan sarana dan prasarana fisik, masyarakat diposisikan sebagai pihak yang menjadi sasaran kegiatan yang di sediakan sarana-prasarana fisik yang menjadi kebutuhannya.

\section{HASIL DAN PEMBAHASAN}

Kegiatan Pengabdian IbM Pengembangan Ekonomi Produktif bagi Kelompok Tani Pembudidaya Ikan di Kabupaten Lebong Melalui Pengembangan Agribisnis Ikan Sepat Siam diawali dengan persiapan, yang meliputi koordinasi dengan tim pelaksana kegiatan 
tentang rencana yang akan dilakukan untuk melaksanakan kegiatan, pengurusan izin kegiatan dengan membawa surat tugas dari Lembaga Pengabdian pada Masyarakat UNIB ke kantor desa Tabeak kauk Kabupaten Lebong, koordinasi dengan Kepala Desa dan kelompok tani mengenai jadwal kegiatan, menyiapkan tempat dan materi penyuluhan, menyiapkan alat-alat dan bahan yang digunakan untuk pelatihan, dan menggandakan handout yang akan dibagikan kepada peserta

Pada tahap pelaksanaan kegiatan, kegiatan yang dilaksanakan pertama kali dilaksanakan adalah 1) Penyuluhan Budidaya Ikan Sepat Siam. Dalam Kegiatan penyuluhan ikan sepat siam diberikan materi tentang manfaat dari pengembangan agribisnis ikan sepat siam, system agribisnis ikan sepat siam mulai dari persiapan kolam, budidaya, dan pengolahan pascapanen. Kegiatan ini dilaksanakan di Balai Desa Tabeak Kauk, yang diikuti oleh anggota kelompok tani Sumber Rezeki dan Kelompok Tani yang berjumlah 30 orang.

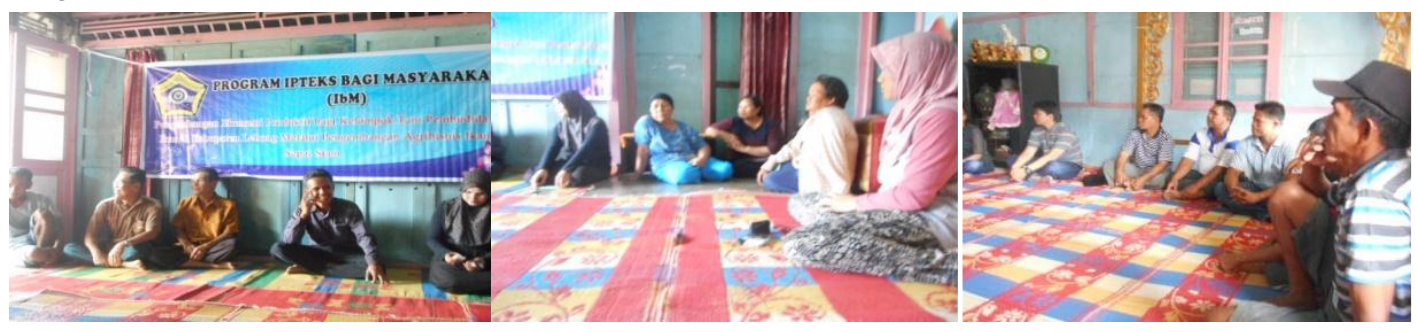

Gambar 1. Penyuluhan budidaya ikan sepat siam

Tahapan pelaksanaan kegiatan yang kedua adalah Persiapan Lokasi Budidaya Ikan Sepat dan Penebaran Bibit. Lahan yang digunakan untuk pembibitan adalah lahan sawah pascapanen padi. Induk ikan sepat disebar dalam lahan sawah yang masih sisa panen.

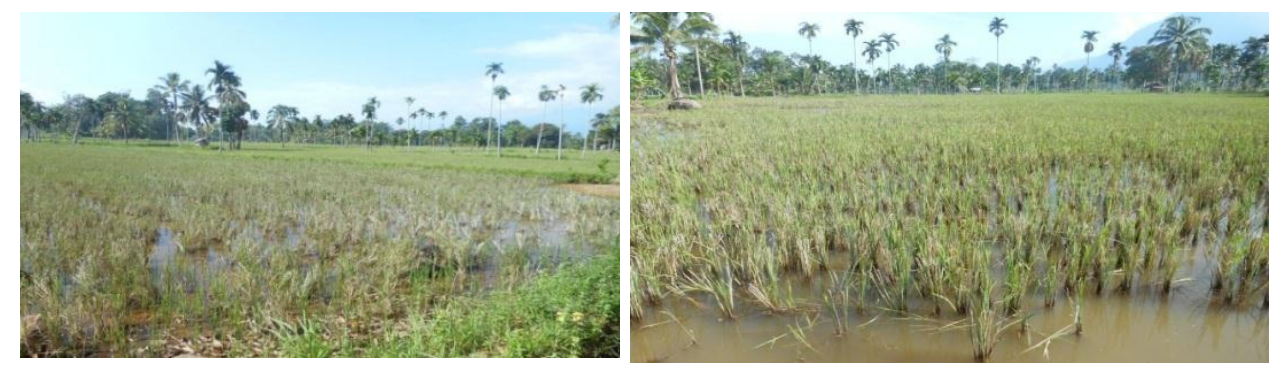

Gambar 2. Persiapan lokasi budidaya ikan sepat dan penebaran bibit

Tahapan kegiatan yang ketiga adalah persiapan Alat dan bahan untuk pelatihan

Pembuatan Pakan ikan. Alat yang digunakan dalam pembuatan pakan ini adalah mesin penepung (grinding), mesin pencetak (pelleting), dan peralatan lainnnya (baskom, ember, timbangan). Bahan yang digunakan untuk pembuatan pakan ikan terdiri dari ampas tahu, ikan rucah, dedak halus, jagung, tepung tapioka, vitamin dan air. Ampas tahu, ikan rucak, dan jagung dijemur sampai kering setelah itu dihaluskan dengan menggunakan mesin penepung. 

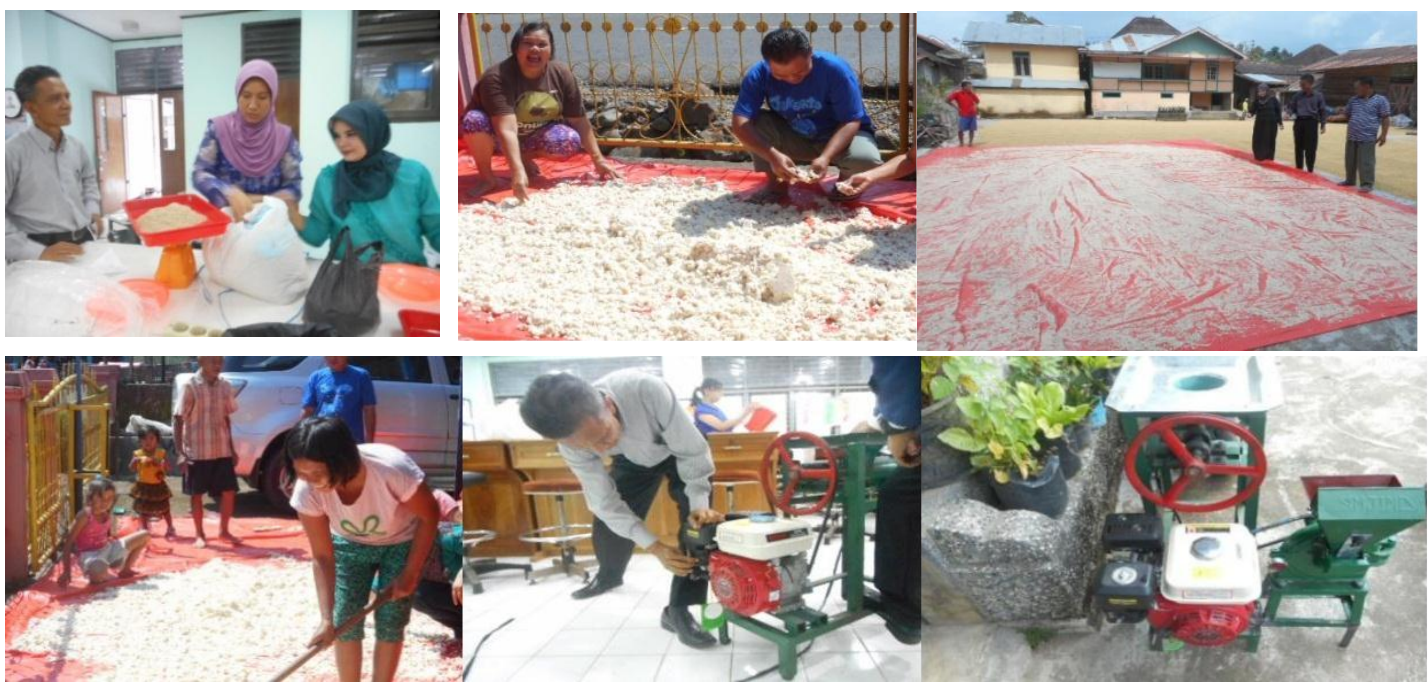

Gambar 3. Persiapan alat dan bahan untuk pelatihan pembuatan pakan ikan

Tahapan pelaksanaan kegiatan yang keempat adalah Pelatihan Pembuatan Pakan. Pembuatan pakan ditujukan untuk mengantisipasi kekurangan pakan yang berasal dari alam yang kontinuitas produksinya tidak dapat dipastikan. Dengan tersedianya pakan buatan ini diharapkan jumlah pakan yang dibutuhkan oleh ikan akan terpenuhi setiap saat. Pakan yang dibuat sesuai dengan kriteria pakan yang berkualitas baik, seperti protein harus sesuai dengan kebutuhan ikan, diameter pakan harus lebih kecil dari ukuran bukaan mulut ikan, pakan mudah dicerna, kandungan nutrisi pakan mudah diserap tubuh, memiliki rasa yang disukai ikan, kandungan abunya rendah, dan tingkat efektivitasnya tinggi. Jenis-jenis pakan yang dibuat adalah bentuk butiran/granules digunakan sebagai pakan benih gelondongan (berumur 40-80 hari). Tepung kasar juga diperoleh dari remah yang dihancurkan atau dibuat sama seperti membuat formulasi pakan lengkap dan bentuknya dibuat menjadi butiran, berbentuk remahan/crumble, digunakan sebagai pakan gelondongan besar/ikan tanggung (berumur 80-120 hari), dan bentuk pellet tenggelam/sinking biasa digunakan untuk kegiatan pembesaran.

Proses pembuatan ikan diawali dengan menyususn formulasi pakan ikan, yaitu adalah protein $30 \%$, lemak, kebutuhannya berkisar antara 4-18\%, karbohidrat, terdiri dari serat kasar, Vitamin dan mineral, kebutuhannya berkisar antara 2-5\%, jumlah keseluruhan bahan baku dalam menyusun formulasi pakan ikan ini harus $100 \%$. Bahan baku yang telah menjadi tepung selanjutnya dilakukan penimbangan sesuai dengan formulasi pakan yang telah dibuat sebelumnya dan diletakkan dalam wadah yang terpisah. Kemudian dilakukan pencampuran bahan baku dari mulai bahan baku yang paling sedikit sampai yang terbanyak. Untuk melihat apakah campuran tersebut benar-benar tercampur buatlah bentuk adonan tersebut bola-bola dan adonan tersebut sudah tidak lengket ditangan. Setelah dilakukan pencampuran bahan 
baku secara homogen langkah selanjutnya adalah membuat pakan buatan sesuai dengan bentuk pakan buatan yang ditentukan. Pakan tersebut kemudian dikeringkan dengan menggunakan menjemur dibawah sinar matahari. Setelah pakan buatan dicetak dan dikeringkan langkah selanjutnya adalah melakukan pengemasan dan penyimpanan pakan.

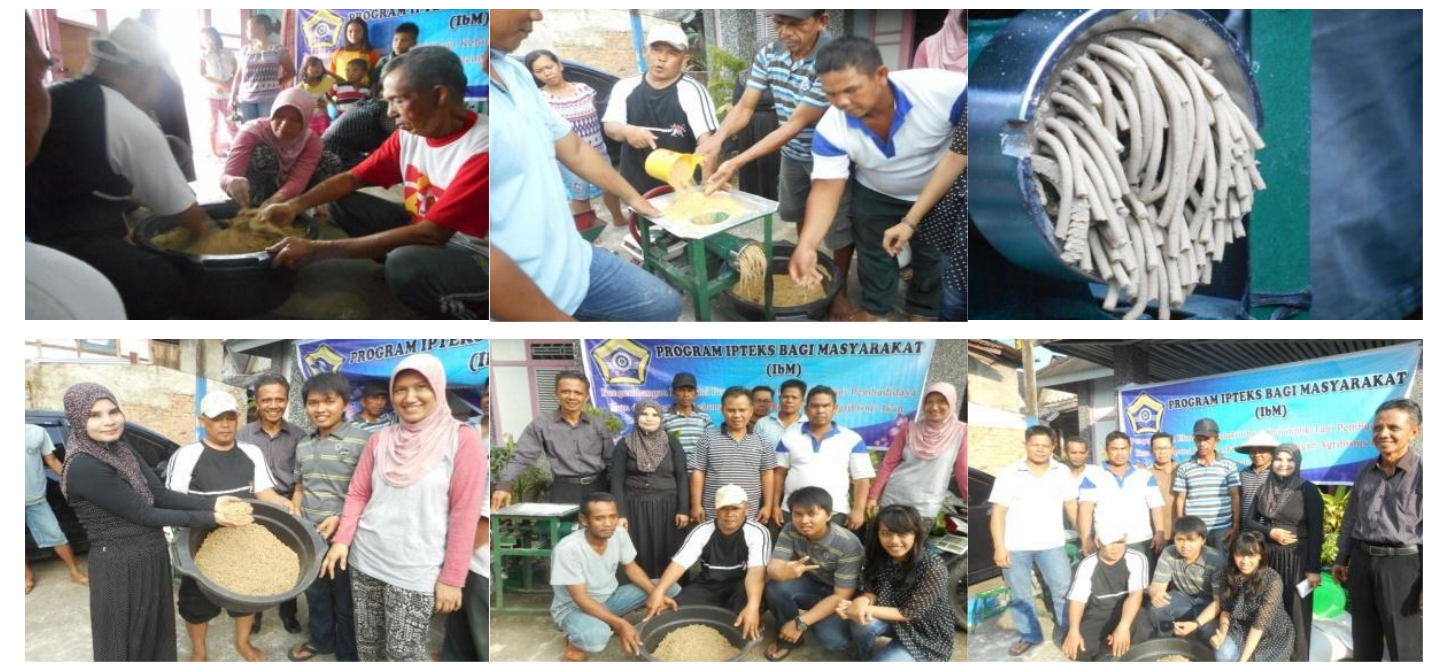

Gambar 4. Pelatihan pembuatan pakan

Tahapan pelaksanaan yang kelima adalah Pembesaran ikan sepat siam dalam kolam terpal. Kegiatan pembesaran dalam kolam terpal ini tidak dapat dilaksanakan karena sumber air untuk mengairi kolam yaitu air dari irigasi kering. Kegiatan budidaya ikan sepat hanya dapat dilakukan selama 3 bulan dikolam sawah. Ikan sepat harus segera dipanen meskipun ukuran ikan masih kecil-kecil karena sawah-sawah mulai mengering. Ikan yang dipanen berukuran 1 sampai 2 jari dengan harga jual Rp. 10,000 per kilogram.

Tahapan pelaksanaan yang keenam adalah Pelatihan Pasca Panen dan Pembentukan Kelompok Usaha Bersama. Ikan merupakan bahan makanan yang mengandung protein yang berkualitas tinggi. Protein dalam kandungan ikan tersusun atas asam amino essensial yang diperlukan oleh tubuh sebagai sumber energi, membantu pertumbuhan dan pemeliharaan tubuh, memperkuat daya tahan tubuh, dan memperlancar proses fisiologi dalam tubuh. Dibanding dengan produk hewani lainnya, ikan memiliki beberapa kelebihan seperti memiliki kandungan protein yang cukup tinggi yaitu 20\%, daging ikan mudah dicerna oleh tubuh, daging ikan mengandung asam-asam lemak tak jenuh dengan kadar kolestrol yang rendah, dan daging ikan sejumlah mineral seperti $\mathrm{K}, \mathrm{Cl}, \mathrm{P}, \mathrm{S}, \mathrm{Mg}, \mathrm{Ca}, \mathrm{Fe}, \mathrm{Ma}, \mathrm{Zn}, \mathrm{Cu}$, vitamin A dan D. Selain memiliki banyak kelebihan, ikan juga memiliki beberapa kekurangan. Ikan merupakan salah satu bahan makanan yang mudah membusuk, bila tidak langsung diberi perlakuan dan penanganan yang tepat setelah ditangkap mutunya akan cepat menurun. Hal ini disebabkan karena ikan mengandung air yang cukup tinggi sehingga cepat rusak dan mengalami pembusukan. Hanya dalam waktu 8 jam sejak ditangkap dan didaratkan sudah akan timbul perubahan yang mengarah pada kerusakan. Kekurangan yang terdapat pada ikan dapat menghambat usaha pemasaran hasil perikanan, tidak jarang 
menimbulkan kerugian besar terutama di saat produksi ikan melimpah. Oleh karena itu, diperlukan proses pengawetan dan pengolahan. Tujuan utama dari pengawetan dan pengolahan adalah untuk mempertahankan ikan dari proses pembusukan sehingga mampu disimpan lama, meningkatkan jangkauan pemasaran, melaksanakan diversifikasi pengolahan produk-produk perikanan, dan meningkatkan pendapatan. Afrianto dan Liviawaty (2005), menyatakan tujuan dari proses pengawatan dan pengolahan adalah memperpanjang daya tahan dan daya simpan ikan. Selain itu, proses pengolahan diperlukan untuk meningkatkan nilai tambah, baik dari segi gizi, rasa, bau, bentuk/tekstur, maupun daya awet. Hasil penelitian menunjukkan bahwa pengolahan ikan menjadi ikan kering dapat meningkatkan nilai tambah sebesar 29,6\%. Salah satu bentuk pengawet dan pengolahan ikan adalah dengan mengasinkan ikan-ikan tersebut. Dengan mengasinkan ikan-ikan tersebut dengan garam, ikan-ikan tersebut akan tahan lebih lama, selain itu juga meningkatkan nilai jual. Selain keuntungan yang menjanjikan, ikan asin juga sangat disenangi oleh masyarakat.

Ikan sepat siam merupakan bahan makanan yang mengandung protein yang berkualitas tinggi. Selain itu, ikan sepat siam ini juga memiliki nilai ekonomi yang tinggi, dimana ikan ini tidak hanya sebagai sumber protein di daerah pedesaan, namun sekarang sudah merupakan sumber protein bagi warga perkotaan bahkan dijadikan sebagai cendramata dan makanan bagi para pengunjung ke daerah penghasil. Selain dijual dalam keadaan segar di pasar, ikan sepat kerap diawetkan dalam bentuk ikan asin sehingga dapat dikirimkan ke tempat-tempat lain. Ikan sepat yang telah kering mengandung energi sebesar 289 kilokalori, protein 38 gram, karbohidrat 0 gram, lemak 14 gram, kalsium 40 miligram, fosfor 100 miligram, dan zat besi 1 miligram. Selain itu di dalam Ikan Sepat Kering juga terkandung vitamin A sebanyak 0 IU, vitamin B1 0 miligram dan vitamin C 0 miligram. Hasil tersebut didapat dari melakukan penelitian terhadap 100 gram Ikan Sepat Kering, dengan jumlah yang dapat dimakan sebanyak $75 \%$.

\section{Proses Pembuatan Ikan Asin}

Tahap-tahap dalam pengolahan ikan asin adalah pembersihan, penggaraman, dan penjemuran.

\section{a. Pembersihan}

Pada tahap ini, pembersihan yang dilakukan adalah pencucian dengan menggunakan air sampai bersih, yang dilakukan pada bak-bak. Setelah bersih bahan baku ikan-ikan tersebut di masukan pada tempat yang disediakan yaitu ember-ember besar.

\section{b. Penggaraman}

Penggunaan garam dalam pembuatan ikan asin berfungsi sebagai pengawet. Sebagai pengawet, garam dapat mengurangi kadar air yang terkandung dalam ikan sehingga dapat menghambat pertumbuhan mikroba dan menghambat aktivitas enzim. Garam yang digunakan dalam pembuatan ikan asin adalah garam dapur atau garam murni $(\mathrm{NaCl})$. 
Penggunaan garam yang muruni akan menghasilkan ikan asin yang berwarna putih dan bertekstur lunak. Jika direndam dalam air, ikan asin akan cepat menyerap air sehingga bila digoreng akan berasa seperti ikan segar. Perbandingan antara bahan baku dengan garam adalah $1: 2$, jadi untuk $1 \mathrm{~kg}$ ikan garam yang dibutuhkan sekitar $2 \mathrm{~kg}$.

\section{c. Penjemuran (Pengeringan)}

Ikan yang telah diproses dalam penggaraman, kemudian dicuci bersih dan langsung dijemur. Aktivitas penjemuran yang bertujuan untuk mengeringkan ikan ini harus dibarengi dengan proses pembalikan yang minimum dilakukan 2-3 kali setiap harinya. Lamanya penjemuran tergantung dari keadaan cuaca tetapi umumnya dibutuhkan waktu 1-2 hari.

Setelah kegiatan pelatihan pengolahan pascapanen ikan sepat, demi keberlanjutan kegiatan dimasa mendatang dibentuk kelompok usaha bersama dengan nama "PASUAK KUTE”, yang memiliki arti Keluarga Besar Desa Tabeak Kauk.
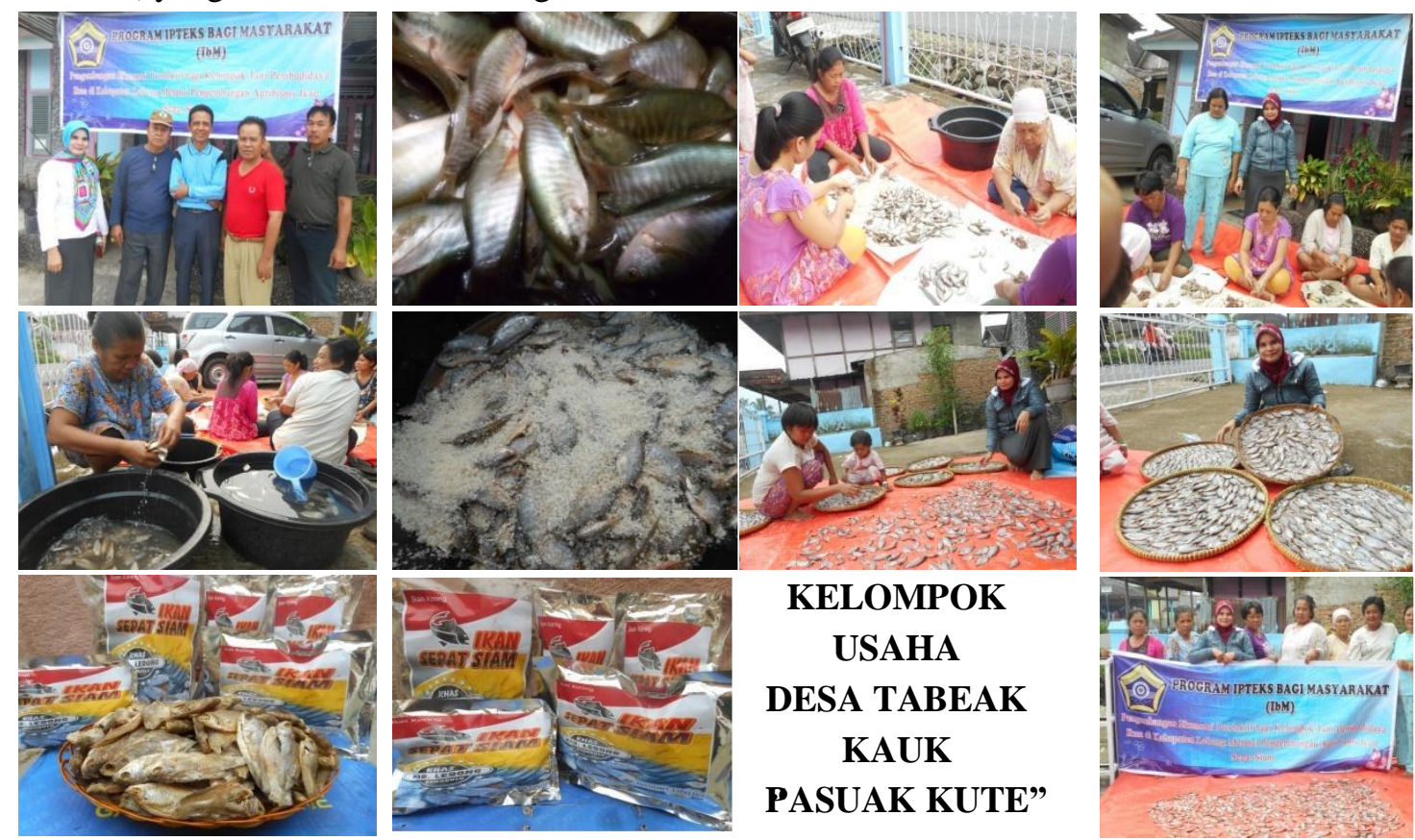

Gambar 5. Proses Pembuatan Ikan Asin

\section{Evaluasi Kegiatan}

Tahap akhir dari kegiatan pengabdian ini adalah evaluasi. Kegiatan ini dilaksanakan dalam dua tahap. Pertama, untuk menilai keberhasilan program kegiatan ini adalah pertama dilihat dari ketertarikan peserta terhadap kegiatan yang dilakukan, $80 \%$ peserta yang diundang hadir dalam pelatihan, terlaksananya kegiatan pelatihan dengan baik, $40 \%$ peserta mampu mengembangkan usaha ekonomi produktif dengan pendampingan dari tim pengabdian pada masyarakat, dan pernyataan kepuasan dari peserta pelatihan, dan pemerintah setempat. 


\section{KESIMPULAN}

Terlaksananya program PPM IbM "Pengembangan Ekonomi Produktif bagi Kelompok Tani Pembudidaya Ikan di Kabupaten Lebong Melalui Pengembangan Agribisnis Ikan Sepat Siam" berkat kerjasama dan partisipasi dari anggota kelompok tani Sumber Rezeki dan kelompok tani Maju Bersama, serta masyarakat desa Tabeak Kauk Kecamatan Lebong Sakti Kabupaten Lebong. Anggota kelompok tani sangat puas dengan pelatihan yang diadakan karena pengetahuan mereka meningkat dalam menyusun formula dan membuat pakan sehingga sangat membantu dalam kegiatan budidaya ikan terutama dalam menangani masalah pakan.

\section{DAFTAR PUSTAKA}

Afrianto, E., dan Liviawaty, 2005, Pakan Ikan : Pembuatan, Penyimpanan, Pengujian, dan Pengembangan, Kanisius, Yogyakarta.

Anonym, 2014. http://www.fishyforum.com/fishysalt/fishydine/11864-cara-membuat-ikanasin-dari-ikan-sepat-siyem.html, diunduh tanggal 10 Maret 2014.

Chambers, R., 2007, From PRA to PLA and Pluralism, Practice and Teory, IDS, Working, http://id.wikipedia.org/wiki/Sepat_rawa, diunduh tanggal 20 April 2014.

Kordi, M., dan Ghufran H., 2011, Panduan Lengkap Memelihara Ikan Air Tawar di Kolam Terpal, Andi, Yogyakarta.

Rukmana, R., 2010, Ikan Sepat Siam "Potensi dan Prospeknya”, CV. Aneka Ilmu, Semarang.

Sahwan, M., Firdaus, 2004, Pakan Ikan dan Udang; Formulasi, Pembuatan, dan Analisis Ekonomi, Penebar Swadaya, Jakarta.

Susanto, H., 2006, Budidaya Ikan di Perkarangan, Penebar Swadaya, Jakarta. 